\title{
The effect of feeding modified soyabean oil enriched with C18:4n-3 to broilers on the deposition of $n-3$ fatty acids in chicken meat
}

\author{
C. Rymer ${ }^{1 *}$, G. F. Hartnell ${ }^{2}$ and D. I. Givens ${ }^{1}$ \\ ${ }^{1}$ School of Agriculture, Policy and Development, University of Reading, PO Box 237, Reading RG6 6AR, UK \\ ${ }^{2}$ Monsanto Company, 800 North Lindbergh Boulevard, O3F, St Louis, MO, USA
}

(Received 13 May 2010 - Revised 9 September 2010 - Accepted 4 October 2010 - First published online 22 November 2010)

\begin{abstract}
Supplementing broiler diets with conventional vegetable oils has little effect on the long-chain $n$ - 3 PUFA (LC $n$-3 PUFA) content of the meat. The present study investigated the effect on fatty acid composition and sensory characteristics of chicken meat when broilers were fed oil extracted from soyabeans (SDASOY) that had been genetically engineered to produce C18: $4 n$-3 (stearidonic acid (SDA), $240 \mathrm{mg} / \mathrm{g}$ oil). Three diets were fed to 120 birds (eight replicate pens of five birds) from $15 \mathrm{~d}$ to slaughter (41-50 d). Diets were identical apart from the oil added to them $(45$ and $50 \mathrm{~g} / \mathrm{kg}$ as fed in the grower and finisher phases, respectively), which was either SDASOY, near-isogenic soya (CON) or fish oil (FISH). The LC $n-3$ PUFA content of the meat increased in the order CON, SDASOY and FISH. In breast meat with skin, the SDA concentration was 522, 13 and 37 (SEM 14.4) mg/100 g meat for SDASOY, CON and FISH, respectively. Equivalent values for C20:5n-3 (EPA) were 53, 13 and 140 (SEM 8-4); for C22:5n-3 (docosapentaenoic acid (DPA)) 65, 15 and 101 (SEM 3.5); for C22:6n-3 (DHA) 19, 9 and 181 (SEM 4.4). Leg meat (with skin) values for SDA were 861, 23 and 68 (SEM 30.1); for EPA 87, 9 and 258 (SEM 7.5); for DPA 95, 20 and 165 (SEM 5.0); for DHA 29, 10 and 278 (SEM 8.4). Aroma, taste and aftertaste of freshly cooked breast meat were not affected. Fishy aromas, tastes and aftertastes were associated with LC $n-3$ PUFA content of the meat, being most noticeable in the FISH leg meat (both freshly cooked and reheated) and in the reheated SDASOY leg meat.
\end{abstract}

Key words: Stearidonic acid: Poultry meat: $n$-3 PUFA

The intake of long-chain $n-3$ PUFA (LC $n-3$ PUFA) in Western diets is low. For example, while the UK minimum daily recommended intake is $450 \mathrm{mg} / \mathrm{d}^{(1)}$, the mean population intake is approximately $244 \mathrm{mg} / \mathrm{d}^{(2)}$, and for many individuals, intakes will be lower still given that $73 \%$ of the population consume no oily fish ${ }^{(2)}$. Enriching chicken meat with LC $n$-3 PUFA can make a nutritionally significant contribution to population LC $n$-3 PUFA intakes, given the high consumption of poultry products by a wide sector of the population ${ }^{(2)}$ and the extent to which poultry meat can be enriched with LC $n$-3 PUFA. To achieve this enrichment with LC $n-3$ PUFA, fish oil is usually included in the broiler $\operatorname{diet}^{(3-8)}$, although algal biomass can also be used ${ }^{(9,10)}$ The long-term sustainability of using fish oil in this way has been questioned ${ }^{(11)}$, while the high price of algal biomass prevents its wide-scale inclusion in poultry diets.

Vegetable sources of $n$-3 PUFA have been investigated, but these generally provide only C18:3n-3 ( $\alpha$-linolenic acid (LNA)). The low conversion efficiency of LNA to LC $n-3$ PUFA and the relatively low concentration of LNA in most vegetable oils result in very low accumulations of LC $n-3$ PUFA in the edible tissues of birds even when fed relatively LNA-rich oils such as linseed ${ }^{(7,12)}$. Stearidonic acid (SDA; C18: $4 n-3$ ) is further along the pathway of conversion of LNA to LC $n-3$ PUFA, and is the product of desaturation by $\Delta-6$ desaturase. It is therefore possible that feeding birds an oil rich in SDA might result in a greater accumulation of LC $n-3$ PUFA in their edible tissues compared with feeding LNA. However, there are few naturally occurring vegetable sources of SDA. Echium (Echium plantagineum) is one of the richest sources, but this only contains approximately $13 \mathrm{~g}$ SDA/100g total fatty acids $^{(13)}$, and feeding birds with echium oil produced breast meat of which a $100 \mathrm{~g}$ serving would provide just $2 \%$ of the recommended daily intake of $450 \mathrm{mg}$ of LC $n-3$ PUFA $^{(14)}$. Plants developed using biotechnology that produce more SDA would increase the amount of this acid that could be fed to birds. This may then increase the degree to which meat might be enriched with LC $n-3$ PUFA. The objective of the present study was to compare

Abbreviations: CON, oil derived from a near-isogenic conventional soyabean variety that did not contain SDA; DPA, docosapentaenoic acid; FISH, feed-grade blended fish oil; LC $n$-3 PUFA, long-chain $n$-3 PUFA; LNA, $\alpha$-linolenic acid; SDA, stearidonic acid; SDASOY, oil derived from soyabeans genetically engineered to produce relatively high concentrations of SDA. 
the effect of feeding conventional soya oil, oil from soyabeans genetically engineered to produce relatively high concentrations of SDA $(240 \mathrm{mg} / \mathrm{g}$ oil), or fish oil to broilers on the fatty acid composition of their edible tissues and the sensory characteristics of their meat.

\section{Materials and methods}

\section{Oils}

Soyabean oils were prepared by POS (Saskatoon, SK, Canada) from soyabeans provided by Monsanto (St Louis, MO, USA). The oil was produced using extraction procedures representative of standard industry practices. Two soyabean oils were produced; the first was derived from soyabeans genetically engineered to produce relatively high concentrations of SDA (SDASOY). The other was derived from a near-isogenic conventional soyabean variety that did not contain SDA (denoted CON). The refined, bleached and deodorised soya oils (SDASOY and CON) were stabilised with $120 \mathrm{mg} / \mathrm{kg}$ tert-butylhydroquinone and $60 \mathrm{mg} / \mathrm{kg}$ citric acid.

Feed-grade blended fish oil was also used (denoted FISH). This was purchased from United Fish Industries (UK) Limited (Grimsby, Lincolnshire, UK). It was not chemically stabilised and so was kept frozen $\left(-20^{\circ} \mathrm{C}\right)$ until use. A sample (approximately $25 \mathrm{~g}$ ) of each oil was taken, stored at $-20^{\circ} \mathrm{C}$ and analysed for fatty acid composition (Table 1).

\section{Birds}

Ross 308 broiler chicks ( $n$ 150) were purchased (PD Hook Hatchery, Bampton, Oxfordshire, UK). The birds used in this experiment were maintained according to the UK

Table 1. Fatty acid composition ( $\mathrm{mg} / \mathrm{g}$ oil) of the oils used in the study

\begin{tabular}{|c|c|c|c|}
\hline \multirow[b]{2}{*}{ Fatty acids } & \multicolumn{3}{|c|}{ Oils } \\
\hline & SDASOY & CON & $\mathrm{FISH}$ \\
\hline C16:0 & 83.8 & $72 \cdot 8$ & $85 \cdot 0$ \\
\hline C16:1 & 0.5 & 0.6 & $37 \cdot 3$ \\
\hline C18:0 & 29.5 & 30.5 & $18 \cdot 4$ \\
\hline C18: 1 cis-9 & 88.2 & 130 & 103 \\
\hline C18: 1 cis-11 & 9.9 & $10 \cdot 1$ & 19.4 \\
\hline C18:2n-6 & 124 & 340 & 39.7 \\
\hline C18:3n-6 & 53.6 & 0 & 0 \\
\hline C18:3n-3 & 69.5 & 49.9 & $11 \cdot 8$ \\
\hline C18:4n-3 & 241 & 0.0 & $14 \cdot 3$ \\
\hline C20: 1 & 0.6 & 0.7 & $22 \cdot 2$ \\
\hline C20 : 4n-6 & 0.6 & 0.0 & $4 \cdot 3$ \\
\hline C20: $3 n-6$ & 0.0 & 0.0 & 1.0 \\
\hline C22: 1 & 0.0 & 0.0 & $42 \cdot 0$ \\
\hline C20: $5 n-3$ & 0.0 & 0.0 & 65.9 \\
\hline C22: 4 & 0.0 & 0.0 & 0.7 \\
\hline C22: $5 n-3$ & 0.0 & 0.0 & $26 \cdot 6$ \\
\hline C22: $6 n-3$ & 0.0 & 0.0 & 71.4 \\
\hline
\end{tabular}

Department of the Environment, Food and Rural Affairs Welfare Code for Poultry. On arrival, the birds were placed in a single pen surrounded with a cardboard ring (to minimise draughts) and kept on wood shavings at a depth of approximately $4 \mathrm{~cm}$. They were fed a common starter diet for $14 \mathrm{~d}$. On day 15 , the birds were weighed. A total of 120 birds were now required; thirty additional birds had been purchased at the start of the experiment to allow for mortality in the first $14 \mathrm{~d}$, and to enable the heaviest and lightest birds to be excluded from the study. Those selected were then assigned to pens randomly within eight blocks (location within the house) of three pens each (total of twenty-four floor pens). The pens had a solid floor with a bedding of wood shavings. There were three treatment diets, and treatments were randomly allocated among each block of three pens. There were a total of eight blocks, and five birds were placed in each pen. The three treatments were diets incorporating either SDASOY, CON or FISH. Water was provided ad libitum via automatic drinkers, and feed was provided ad libitum via hoppers (Super Feeder Hopper $3 \mathrm{~kg}, 07400$; Stockshop, Exeter, Devon, UK). The birds were fed a grower diet from days 15 to 28 and a finisher diet from days 29 to 50 . Feed added and removed from pens was weighed and recorded. Diet changes were conducted at the same time for all pens.

Birds were weighed again at $41 \mathrm{~d}$, and the amount of feed consumed per pen from 15 to $41 \mathrm{~d}$ was recorded. Performance data were calculated and summarised by average weight gain per bird between 15 and $41 \mathrm{~d}$ of age. The mean adjusted feed:gain ratio was calculated per pen by dividing total feed consumption by the weight gain of surviving birds plus the weight gain of birds that died. Birds were slaughtered in blocks of two on days 41, 43, 48 and 50 and left to hang (after being plucked and eviscerated) in a cold store overnight. The following day, the total amount of breast skin, leg skin, breast meat and boned leg meat was recorded, and samples of breast skin, breast meat and leg meat were taken, composited by pen and stored frozen $\left(-20^{\circ} \mathrm{C}\right)$ for the pending analysis of fatty acid composition. Breast skin was analysed rather than leg skin, as it was considered that breast skin would be less prone to damage from bruising. Samples of skinless breast and leg meat, composited by treatment, were also taken for sensory analysis, and stored frozen $\left(-20^{\circ} \mathrm{C}\right)$.

\section{Diets}

Seven diets (Table 2) were manufactured (SDS, Witham, Essex, UK). The common starter diet contained CON. The grower and finisher diets incorporated one of the three oils (CON, SDASOY or FISH). The respective oil was added as the final ingredient in the manufacture of each diet, and mixed for between 5 and $15 \mathrm{~min}$ in a horizontal ribbon mixer. The starter diet was fed as a mash, but the other diets were pelleted (Kubex Pellet Mill, 
Table 2. Formulation of diets used

\begin{tabular}{|c|c|c|c|c|c|c|c|}
\hline \multirow[b]{2}{*}{ Ingredients (g/kg as fed) } & \multirow[b]{2}{*}{ Starter } & \multicolumn{3}{|c|}{ Grower } & \multicolumn{3}{|c|}{ Finisher } \\
\hline & & SDASOY & CON & FISH & SDASOY & CON & $\mathrm{FISH}$ \\
\hline Wheat & 475 & 502 & 502 & 502 & 569 & 569 & 569 \\
\hline Soyabean meal & 325 & 300 & 300 & 300 & 247 & 247 & 247 \\
\hline Sunflower seed meal & 26 & 4 & 4 & 4 & 20 & 20 & 20 \\
\hline Maize gluten meal & 40 & 65 & 65 & 65 & 30 & 30 & 30 \\
\hline $\mathrm{CaCO}_{3}$ & 15 & 12 & 12 & 12 & 6 & 6 & 6 \\
\hline Dicalcium phosphate & 20 & 12 & 12 & 12 & 20 & 20 & 20 \\
\hline SDASOY & 0 & 45 & 0 & 0 & 50 & 0 & 0 \\
\hline CON & 40 & 0 & 45 & 0 & 0 & 50 & 0 \\
\hline FISH & 0 & 0 & 0 & 45 & 0 & 0 & 50 \\
\hline Salt & 4 & 2.5 & 2.5 & 2.5 & 2.5 & 2.5 & $2 \cdot 5$ \\
\hline Vitamin/mineral supplements ${ }^{\star}$ & 50 & 50 & 50 & 50 & 50 & 50 & 50 \\
\hline DL-Met & 2 & 2 & 2 & 2 & 2 & 2 & 2 \\
\hline Lys & 3 & 4 & 4 & 4 & 2 & 2 & 2 \\
\hline $\mathrm{NaHCO}_{3}$ & 1.5 & 1.5 & 1.5 & 1.5 & 1.5 & 1.5 & 1.5 \\
\hline
\end{tabular}

SDASOY, oil derived from soyabeans genetically engineered to produce relatively high concentrations of stearidonic acid (SDA); CON oil derived from a near-isogenic conventional soyabean variety that did not contain SDA; FISH, feed-grade blended fish oil. ${ }^{*}$ For composition of the supplements, see Table 3 .

Bühler, Uzwil, Switzerland) using a $4 \mathrm{~mm}$ die. The pelleting temperature was kept between 50 and $60^{\circ} \mathrm{C}$. Knives were set to make the pellet size as small as possible for the grower diets, but up to $7 \mathrm{~mm}$ length for the finisher diets. The pellets were screened and placed on trays before being placed in a drier at approximately $30^{\circ} \mathrm{C}$ overnight (Laboratory Thermal Equipment, Greenfield, Oldham, UK). Diets were stored in sealed plastic buckets. The grower and finisher diets were stored frozen until approximately $3 \mathrm{~d}$ before being fed; they were then transferred to a cold room (approximately $4^{\circ} \mathrm{C}$ ) until they were fed to the birds. Within each phase, diets were formulated to have equal concentrations of apparent metabolisable energy, lipid, available lysine, methionine and other essential amino acids. The composition of the diets is detailed in Table 2, and the composition of the vitamin/mineral premixes that were added to the diets is detailed in Table 3 . The vitamin E content of the finisher diets was DL- $\alpha$-tocopherol $(50 \mathrm{mg} / \mathrm{kg})$. A running sample was taken of each diet by taking approximately $50 \mathrm{~g}$ of feed each day and adding it to a bulked sample that was kept at $-20^{\circ} \mathrm{C}$. At the end of the feeding trial, this bulked sample was thoroughly mixed and then stored at $-20^{\circ} \mathrm{C}$ before being analysed for fatty acids.

\section{Fatty acid analysis}

Samples of milled ( $1 \mathrm{~mm}$ screen) feed or homogenised tissue were defrosted and analysed for fatty acids. Samples of feed $(10 \mathrm{~g}$ ), meat (approximately $20 \mathrm{~g}$ ) or skin (approximately $10 \mathrm{~g}$ ) were homogenised with $40 \mathrm{ml}$ methanol and $20 \mathrm{ml}$ chloroform for $2 \mathrm{~min}$. A further $20 \mathrm{ml}$ chloroform was added, and the mixture was homogenised for $30 \mathrm{~s}$. The chloroform contained butylated hydroxytoluene $(0.01 \mathrm{~g} / 100 \mathrm{ml})$. Distilled water $(20 \mathrm{ml})$ was then added, and the mixture was homogenised for a further $30 \mathrm{~s}$. The mixture was then filtered, and the filtrate was poured into a separating funnel. The chloroform extract was then poured into a round-bottomed flask and evaporated on a rotary evaporator. A mixture of chloroform-methanol $(2: 1, \mathrm{v} / \mathrm{v})$ was then added $(25 \mathrm{ml}$ for feed, $20 \mathrm{ml}$ for meat and $100 \mathrm{ml}$ for skin). A sample $(1 \mathrm{ml})$ of this extract was then pipetted into a $10 \mathrm{ml}$ tube and dried under a stream of $\mathrm{N}_{2}$. The residue was dissolved in dried toluene $(1 \mathrm{ml})$ and sodium methoxide $(0.5 \mathrm{~m}$ in methanol, $2 \mathrm{ml})$ to methylate the fatty acids. The tube was capped and then heated on a heating block set at $60^{\circ} \mathrm{C}$ for $30 \mathrm{~min}$. Glacial acetic acid $(0.1 \mathrm{ml})$ and hexane $(2 \mathrm{ml}$, containing an internal standard, docosane) were then added and mixed, followed by water $(5 \mathrm{ml})$. The presence of docosane in these particular samples was not separately analysed, but previous

Table 3. Composition of the vitamin/mineral supplements that were used

\begin{tabular}{|c|c|c|c|}
\hline \multirow[b]{2}{*}{ Ingredients } & \multicolumn{3}{|c|}{$\begin{array}{l}\text { Inclusion in supplement } \\
\text { ( } g / \mathrm{kg} \text { fresh weight) }\end{array}$} \\
\hline & Starter & Grower & Finisher \\
\hline Wheat & 908.4 & $915 \cdot 7$ & $921 \cdot 5$ \\
\hline Choline chloride (50\%) & $76 \cdot 0$ & 69.4 & 64.7 \\
\hline Manganese oxide (62\%) & 3.9 & 3.9 & 3.9 \\
\hline DL- $\alpha$-Tocopherol acetate $(50 \%)$ & $3 \cdot 0$ & $2 \cdot 0$ & $2 \cdot 0$ \\
\hline Zinc oxide $(72 \%)$ & $2 \cdot 8$ & $2 \cdot 8$ & $2 \cdot 8$ \\
\hline Copper sulphate $(25 \%)$ & $1 \cdot 3$ & $1 \cdot 3$ & $1 \cdot 3$ \\
\hline Nicotinic acid $(99 \%)$ & $1 \cdot 1$ & $1 \cdot 1$ & 0.7 \\
\hline Ferrous sulphate monohydrate (30\%) & $1 \cdot 1$ & 1.5 & $1 \cdot 1$ \\
\hline $\operatorname{Se}(1 \%)$ & $0 \cdot 6$ & $0 \cdot 6$ & $0 \cdot 6$ \\
\hline Cyanocobalamine $(0.1 \%)$ & 0.3 & 0.3 & $0 \cdot 2$ \\
\hline Calcium D-pantothenate (97.5\%) & $0 \cdot 3$ & $0 \cdot 3$ & $0 \cdot 3$ \\
\hline Retinol $(300 \mathrm{mg} / \mathrm{g})$ & 0.2 & $0 \cdot 2$ & $0 \cdot 2$ \\
\hline Biotin $(2 \%)$ & 0.2 & $0 \cdot 2$ & $0 \cdot 1$ \\
\hline Vitamin $\mathrm{B}_{2}$ (riboflavin, $80 \%$ ) & 0.2 & $0 \cdot 2$ & $0 \cdot 1$ \\
\hline Cholecalciferol (12.5 mg/g) & 0.2 & 0.2 & 0.2 \\
\hline Menadione sodium bisulphite (51.5\%) & $0 \cdot 1$ & $0 \cdot 1$ & $0 \cdot 1$ \\
\hline Pyridoxine hydrochloride (99\%) & $0 \cdot 1$ & $0 \cdot 1$ & 0.1 \\
\hline Thiamine hydrochloride (99\%) & 0.1 & 0.04 & 0.04 \\
\hline Folic acid (95\%) & 0.05 & 0.03 & 0.03 \\
\hline Potassium iodate $(59 \% \mathrm{l})$ & 0.05 & 0.03 & 0.03 \\
\hline
\end{tabular}


(unpublished results) determinations at this laboratory have detected only negligible amounts of this compound in poultry meat. The organic layer $(3 \mathrm{ml})$ containing the fatty acid methyl esters was then separated off and analysed using a GC-MS (GCD Series 2; Hewlett Packard, Palo Alto, CA, USA). Samples were injected (split injection) onto a capillary column $(60 \mathrm{~m}$ and $0.32 \mathrm{~mm}$ in diameter) with $\mathrm{He}$ (flow rate $1 \mathrm{ml} / \mathrm{min}$ ) used as the carrier gas. The column was held at $70^{\circ} \mathrm{C}$ for $2 \mathrm{~min}$ before being raised to $165^{\circ} \mathrm{C}\left(5^{\circ} \mathrm{C} / \mathrm{min}\right)$ for $5 \mathrm{~min}$. It was then raised to $180^{\circ} \mathrm{C}\left(6^{\circ} \mathrm{C} / \mathrm{min}\right)$ for $10 \mathrm{~min}$ and then $230^{\circ} \mathrm{C}\left(3^{\circ} \mathrm{C} / \mathrm{min}\right)$ for $3 \mathrm{~min}$. The inlet temperature was $260^{\circ} \mathrm{C}$, and the detector temperature was $250^{\circ} \mathrm{C}$. Fatty acid methyl esters were identified by comparing retention times with those of standards, and quantification was done by calculating the areas under the curve and comparing these with standards. Concentrations were calculated as $\mu \mathrm{g} / \mathrm{ml}$ solution injected on the column. Fatty acid concentrations were then calculated in terms of $\mathrm{mg}$ fatty acid/100 $\mathrm{g}$ tissue (fresh weight).

\section{Sensory analysis}

Samples of breast and leg meat were subjected to sensory analysis (Sensory Dimensions Limited, Reading, UK). The present study was conducted according to the guidelines laid down in the Declaration of Helsinki, and all procedures involving human subjects were approved by the University of Reading School of Agriculture, Policy and Development ethics committee. Written informed consent was obtained from all subjects. Breast meat was assessed when freshly cooked, while leg meat was assessed when freshly cooked and when it had been cooked, refrigerated and then reheated. This was because the higher lipid content of the leg meat was likely to make it more prone to oxidative deterioration, and reheating the meat would provide a greater oxidative stress so as to increase the likelihood of detecting any differences in the oxidative stability of the lipid component of the meat ${ }^{(15)}$.

Boneless, skinless fillets of the meat were supplied vacuum packed and frozen. They were then transferred to $20^{\circ} \mathrm{C}$ and defrosted completely $12 \mathrm{~h}$ before cooking. Samples were wrapped in aluminium foil and cooked in a preheated oven at $180^{\circ} \mathrm{C}$ for $30 \mathrm{~min} / 500 \mathrm{~g}$. The meat was then cooled to room temperature $\left(20^{\circ} \mathrm{C}\right)$ before serving. The reheated samples were prepared by cooling cooked samples and then refrigerating them $\left(5^{\circ} \mathrm{C}\right)$ overnight. The following day, samples were reheated at $180^{\circ} \mathrm{C}$ for $30 \mathrm{~min}$ and then allowed to cool to room temperature $\left(20^{\circ} \mathrm{C}\right)$ before serving. Sensory analysis of the meats was done (breast meat and leg meat was done separately, but freshly cooked and reheated leg meat was analysed together) by ten trained assessors using quantitative descriptive analysis ${ }^{(16)}$, with each panelist assessing three replicates of each sample over a period of $6 \mathrm{~d}$. Plain crackers and mineral water were used as palate cleansers between samples. Samples were tasted and chewed, and then spat out rather than being swallowed. The aftertaste of samples was determined 1 min after the samples had been removed from the mouth.

\section{Data analysis}

The effect of the broiler diet on bird performance and tissue fatty acid composition was determined by ANOVA, taking block into account. Tukey's multiple comparison test was used to identify which treatments were significantly different from each other when the significance was $P<0.05$. Skinless breast meat, skinless leg meat and skin were analysed separately. The calculated fatty acid composition of breast meat and leg meat (with the skin on) was then determined, taking into account the relative proportions of skinless meat and skin in the breast and leg. This estimate of proportion of skinless meat to skin was done on a pen basis. The effect of tissue type and broiler diet on the sensory attributes of the meat was analysed by ANOVA and Fisher's least significant difference multiple comparison test.

\section{Results}

\section{Bird performance}

Between 15 and $41 \mathrm{~d}$, a total of four birds died; there was, however, no evidence to suggest that the diet fed to the birds had any effect on bird health. The effects of the diet on mean feed intake from 15 to $41 \mathrm{~d}$, weight gain, adjusted feed:gain ratio and yields of meat are presented in Table 4. There was no significant difference between treatments in DM intake, weight gain or feed conversion efficiency. The slaughter, dressed and cold carcass weights, and the weight of the breast meat and the whole leg of birds fed FISH were lower than those of birds fed CON. Yields of the total and breast meat ( $\%$ of slaughter weight) were also lower for birds fed FISH than for birds fed SDASOY. The proportion of skin in the breast and leg was not affected by the diet.

\section{Fatty acid composition}

The fatty acid composition of the diets is summarised in Table 5. Diets containing fish oil (FISH) had much higher concentrations of C16:1, C18:1cis-11, C20:1, C22 : 1, EPA, docosapentaenoic acid (DPA) and DHA compared with the other diets. The CON diets had a higher concentration of $\mathrm{C} 18: 2 n-6$. The SDASOY diets had higher concentrations of C18:3n-6 and SDA compared with the other diets.

The effect of the diet on the fatty acid composition of skinless breast meat, skinless leg meat and skin is presented in Tables 6-8. The calculated fatty acid composition of breast and leg meat (with the skin on) is also presented (Tables 9 and 10), taking account of the relative 
Table 4. Effect of the diets on bird performance

(Mean values with their standard errors)

\begin{tabular}{|c|c|c|c|c|c|}
\hline & \multicolumn{3}{|c|}{ Diets } & \multirow[b]{2}{*}{ SEM } & \multirow[b]{2}{*}{$P$} \\
\hline & SDASOY & $\mathrm{CON}$ & FISH & & \\
\hline Feed intake (g DM/bird) & 3540 & 3707 & 3506 & $61 \cdot 0$ & 0.076 \\
\hline Wt gain (g/bird) & 2504 & 2618 & 2570 & $72 \cdot 8$ & 0.553 \\
\hline Adjusted feed:gain ratio & 1.5 & 1.5 & 1.5 & 0.01 & 0.291 \\
\hline \multicolumn{6}{|l|}{ Carcase and meat weights ( $\mathrm{g} / \mathrm{bird}$ ) } \\
\hline Slaughter wt & $3661^{a, b}$ & $3711^{\mathrm{a}}$ & $3513^{b}$ & $59 \cdot 0$ & 0.048 \\
\hline Dressed wt & $2752^{a, b}$ & $2808^{a}$ & $2602^{b}$ & $51 \cdot 1$ & 0.014 \\
\hline Cold carcass wt & $2735^{a, b}$ & $2791^{\mathrm{a}}$ & $2600^{b}$ & 51.5 & 0.028 \\
\hline Breast skin & 81 & 73 & 75 & 2.5 & 0.097 \\
\hline Breast meat & $813^{\mathrm{a}}$ & $833^{\mathrm{a}}$ & $740^{\mathrm{b}}$ & $17 \cdot 1$ & $<0.001$ \\
\hline Whole leg & $746^{a, b}$ & $755^{\mathrm{a}}$ & $691^{\mathrm{b}}$ & $17 \cdot 2$ & 0.020 \\
\hline Leg skin & 75 & 77 & 70 & $2 \cdot 4$ & 0.067 \\
\hline Leg meat & 505 & 522 & 481 & 11.7 & 0.051 \\
\hline \multicolumn{6}{|l|}{ Yields of meat ( $\%$ of slaughter weight) } \\
\hline Plucked, eviscerated carcass wt & $75 \cdot 1$ & $75 \cdot 3$ & 73.9 & 0.47 & 0.086 \\
\hline Breast meat yield & $22 \cdot 1^{\mathrm{a}}$ & $22 \cdot 2^{\mathrm{a}}$ & $21.0^{\mathrm{b}}$ & 0.24 & $<0.001$ \\
\hline Leg meat yield & $13 \cdot 8$ & $13 \cdot 9$ & $13 \cdot 6$ & 0.17 & 0.462 \\
\hline Total meat yield & $35 \cdot 9^{\mathrm{a}}$ & $36 \cdot 2^{\mathrm{a}}$ & $34 \cdot 6^{\mathrm{b}}$ & 0.31 & 0.001 \\
\hline Skin in breast (\%) & 8.5 & 8.8 & $9 \cdot 0$ & 0.21 & 0.232 \\
\hline Skin in leg (\%) & $12 \cdot 9$ & $12 \cdot 9$ & $12 \cdot 7$ & 0.29 & 0.793 \\
\hline
\end{tabular}

SDASOY, oil derived from soyabeans genetically engineered to produce relatively high concentrations of stearidonic acid (SDA); CON, oil derived from a near-isogenic conventional soyabean variety that did not contain SDA; FISH, feed-grade blended fish oil.

${ }^{a, b}$ Mean values within a row with unlike superscript letters were significantly different $(P<0.05)$.

proportions of skin and meat recorded in the breast and leg. There was no effect of the diet on the concentrations $(\mathrm{mg} / 100 \mathrm{~g}$ fresh tissue) of $\mathrm{C} 16: 0, \mathrm{C} 16: 1, \mathrm{C} 18: 0$ and C18:1 in the skinless breast meat and skinless leg meat. However, the concentration of $\mathrm{C} 16: 0$ was greater in the skin, and in the meat with skin, when birds were fed CON rather than FISH. The concentration of $\mathrm{C} 16: 1$ and C18:1cis-11 was lower in these tissues when birds were fed SDASOY compared with the other diets, while the concentration of C18:1cis-9 was higher when birds were fed CON. The concentration of C18:0 was lower in the skin and breast meat with skin when birds were fed FISH.

The concentrations of $\mathrm{C} 18: 2 n-6, \mathrm{C} 20: 4 n-6$ and $\mathrm{C} 22: 5 n$ 6 were greater in all tissues (except skin for C20:4) when birds were fed CON rather than SDASOY or FISH. However, the concentration of $\mathrm{C} 18: 3 n-6$ was low or negligible in all tissues apart from those that contained skin or from birds that had been fed SDASOY. In the $n$ - 3 series, the concentration of LNA was greater when birds were

Table 5. Fatty acid composition ( $\mathrm{mg} / 100 \mathrm{~g}$ feed, fresh weight) of the diets used in the present study

\begin{tabular}{|c|c|c|c|c|c|c|c|}
\hline \multirow[b]{3}{*}{ Fatty acids } & \multicolumn{7}{|c|}{ Diets } \\
\hline & \multirow[b]{2}{*}{ Starter } & \multicolumn{3}{|c|}{ Grower phase } & \multicolumn{3}{|c|}{ Finisher phase } \\
\hline & & SDASOY & $\mathrm{CON}$ & FISH & SDASOY & CON & $\mathrm{FISH}$ \\
\hline C16:0 & 547 & 515 & 478 & 686 & 551 & 578 & 572 \\
\hline C16:1 & 5 & 4 & 4 & 202 & 3 & 5 & 184 \\
\hline C18:0 & 164 & 152 & 159 & 122 & 147 & 182 & 100 \\
\hline C18: 1 cis-9 & 813 & 583 & 742 & 746 & 583 & 914 & 633 \\
\hline C18: 1cis-11 & 58 & 53 & 53 & 114 & 53 & 66 & 89 \\
\hline C18:2n-6 & 2164 & 1194 & 2124 & 975 & 1108 & 2411 & 697 \\
\hline C18:3n-6 & 2 & 224 & 8 & 4 & 207 & 1 & 2 \\
\hline C18:3n-3 & 312 & 381 & 291 & 156 & 389 & 347 & 122 \\
\hline C18:4n-3 & 0 & 968 & 0 & 68 & 1018 & 0 & 63 \\
\hline C20: 1 & 0 & 4 & 2 & 80 & 0 & 0 & 77 \\
\hline $\mathrm{C} 20: 4 n-6$ & 0 & 2 & 6 & 17 & 0 & 0 & 8 \\
\hline C20:3n-6 & 0 & 4 & 0 & 3 & 0 & 0 & 2 \\
\hline C22:1 & 0 & 0 & 0 & 129 & 0 & 0 & 156 \\
\hline C20: $5 n-3$ & 0 & 0 & 0 & 291 & 0 & 0 & 278 \\
\hline C22: 4n-6 & 0 & 0 & 0 & 0 & 0 & 0 & 1 \\
\hline C22: $5 n-3$ & 0 & 1 & 0 & 91 & 0 & 0 & 105 \\
\hline C22: $6 n-3$ & 0 & 0 & 0 & 253 & 0 & 0 & 289 \\
\hline
\end{tabular}

SDASOY, oil derived from soyabeans genetically engineered to produce relatively high concentrations of stearidonic acid (SDA); CON, oil derived from a near-isogenic conventional soyabean variety that did not contain SDA; FISH, feed-grade blended fish oil. 
Table 6. Effect of the diets on the fat content and fatty acid composition ( $\mathrm{mg} / 100 \mathrm{~g}$ fresh tissue) of skinless breast meat (Mean values with their standard errors)

\begin{tabular}{|c|c|c|c|c|c|}
\hline \multirow[b]{2}{*}{ Fatty acids } & \multicolumn{3}{|c|}{ Diets } & \multirow[b]{2}{*}{ SEM } & \multirow[b]{2}{*}{$P$} \\
\hline & SDASOY & CON & FISH & & \\
\hline Fat content $(\mathrm{g} / \mathrm{kg})$ & $39 \cdot 4$ & 39.9 & $29 \cdot 9$ & $2 \cdot 92$ & 0.050 \\
\hline C16:0 & 461 & 435 & 351 & $44 \cdot 2$ & 0.223 \\
\hline C16:1 & 63 & 73 & 78 & 9.4 & 0.561 \\
\hline C18:0 & 168 & 151 & 121 & 14.5 & $0 \cdot 101$ \\
\hline C18:1cis-9 & 499 & 581 & 391 & $49 \cdot 6$ & 0.052 \\
\hline C18:1cis-11 & 39 & 50 & 48 & $4 \cdot 19$ & 0.174 \\
\hline C18:2n-6 & $395^{\mathrm{a}}$ & $635^{\mathrm{b}}$ & $223^{\mathrm{a}}$ & $50 \cdot 3$ & $<0.001$ \\
\hline C18:3n-6 & $53^{b}$ & $3^{a}$ & $2^{a}$ & $4 \cdot 1$ & $<0.001$ \\
\hline C18:3n-3 & $116^{\mathrm{b}}$ & $80^{b}$ & $31^{a}$ & $9 \cdot 8$ & $<0.001$ \\
\hline C18: $4 n-3$ & $231^{\mathrm{b}}$ & $3^{\mathrm{a}}$ & $13^{a}$ & $19 \cdot 0$ & $<0.001$ \\
\hline C20: 1 & $2^{\mathrm{a}}$ & $2^{\mathrm{a}}$ & $11^{\mathrm{b}}$ & 1.5 & 0.001 \\
\hline$C 20: 4 n-6$ & $24^{\mathrm{b}}$ & $32^{\mathrm{c}}$ & $13^{\mathrm{a}}$ & $2 \cdot 1$ & $<0.001$ \\
\hline C20:3n-6 & $8^{a, b}$ & $15^{\mathrm{b}}$ & $2^{a}$ & $2 \cdot 8$ & 0.021 \\
\hline $\mathrm{C} 20: 5 n-3$ & $28^{a, b}$ & $12^{\mathrm{a}}$ & $49^{b}$ & 9.4 & 0.044 \\
\hline C22: $5 n-6$ & $0.9^{\mathrm{a}}$ & $3 \cdot 1^{\mathrm{b}}$ & $0.5^{\mathrm{a}}$ & 0.21 & $<0.001$ \\
\hline C22: $5 n-3$ & $45^{b}$ & $12^{\mathrm{a}}$ & $53^{b}$ & $3 \cdot 3$ & $<0.001$ \\
\hline $\mathrm{C} 22: 6 n-3$ & $14^{\mathrm{b}}$ & $7^{\mathrm{a}}$ & $107^{\mathrm{c}}$ & $4 \cdot 7$ & $<0.001$ \\
\hline SFA & 629 & 587 & 473 & $58 \cdot 0$ & 0.181 \\
\hline MUFA & 602 & 706 & 527 & $62 \cdot 5$ & 0.164 \\
\hline PUFA & $915^{\mathrm{b}}$ & $803^{b}$ & $495^{\mathrm{a}}$ & $75 \cdot 1$ & 0.004 \\
\hline Total $n-3^{\star}$ & $434^{c}$ & $114^{\mathrm{a}}$ & $253^{b}$ & $33 \cdot 3$ & $<0.001$ \\
\hline Total $n-6 \dagger$ & $472^{b}$ & $670^{c}$ & $239^{a}$ & $52 \cdot 0$ & $<0.001$ \\
\hline$n-6: n-3 \ddagger$ & $1 \cdot 11^{\mathrm{a}}$ & $6 \cdot 13^{\mathrm{b}}$ & $0.93^{\mathrm{a}}$ & 0.185 & $<0.001$ \\
\hline LC $n$-3 PUFA§ & $87^{b}$ & $31^{\mathrm{a}}$ & $209^{c}$ & $15 \cdot 0$ & $<0.001$ \\
\hline LC $n-3$ PUFA equivalents\| & $164^{\mathrm{b}}$ & $32^{\mathrm{a}}$ & $213^{\mathrm{b}}$ & $17 \cdot 2$ & $<0.001$ \\
\hline $\begin{array}{l}\text { SDASOY, oil derived from soya } \\
\text { derived from a near-isogenic } \\
\text { long-chain } n-3 \text { PUFA. } \\
\text { a,b,c Mean values within a row w } \\
{ }^{*} \text { Total } n-3 \text { fatty acids. } \\
\text { †Total } n-6 \text { fatty acids. } \\
\text { f Ratio of } n-6: n-3 \text { fatty acids. } \\
\text { § Total LC } n-3 \text { PUFA. } \\
\text { ॥ Calculated as (C18: } 4 n-3 \times 0.3\end{array}$ & $\begin{array}{l}\text { etically engin } \\
\text { nal soyabean } \\
\text { uperscript lett }\end{array}$ & $\begin{array}{l}\text { roduce rela } \\
\text { at did not c } \\
\text { ignificantly }\end{array}$ & $\begin{array}{l}\text { A; FISH, fe } \\
\text { P<0.05). }\end{array}$ & $\begin{array}{l}\text { earidonic a } \\
\text { olended fis }\end{array}$ & $\begin{array}{l}\text {; CON, oil } \\
\text { ר-3 PUFA, }\end{array}$ \\
\hline
\end{tabular}

fed soya oil (CON or SDASOY) rather than FISH, but the concentration of SDA was much higher in all tissues when birds were fed SDASOY. The concentration of EPA, DPA and DHA was highest in all tissues when birds were fed FISH. However, there were significantly higher concentrations of both EPA and DPA when birds were fed SDASOY rather than CON. The exception to this was in the skinless breast meat where the difference in EPA content in SDASOY and CON was not significant, but in the skinless breast meat, the DPA content was significantly greater in the SDASOY meat compared with the CON meat and, indeed, there was no significant difference in DPA content between birds fed either FISH or SDASOY. The concentration of DHA was greatest in all tissues when birds were fed FISH, and apart from the skinless breast meat, there was no significant difference in the DHA content of tissues from birds fed either SDASOY or CON.

The concentrations of total SFA and MUFA were not affected by the diet in the skinless leg or breast meat, but in tissues with skin, SFA were higher in CON compared with FISH, while MUFA were higher in CON compared with both FISH and SDASOY. Total PUFA content was higher in all tissues (except in the skinless leg meat) when birds were fed soya oil (CON or SDASOY) rather than FISH. Total $n$-3 PUFA content was greatest in tissues when birds were fed SDASOY, but the content was also significantly greater in birds fed FISH compared with those fed CON. However, LC $n$-3 PUFA content was greatest in all tissues when birds were fed FISH, although birds fed SDASOY still had significantly higher LC $n-3$ PUFA contents in their tissues compared with birds fed CON. A $100 \mathrm{~g}$ serving of skinless breast meat or leg meat with skin would provide 46 and $156 \%$, respectively, of the minimum recommended LC $n-3$ PUFA intake of $450 \mathrm{mg} / \mathrm{d}^{(1)}$ if birds were fed FISH. The equivalent figures for meat from birds fed SDASOY were 19 and $47 \%$, while for the CON meat, they were just 7 and $8 \%$. The concentration of LC $n-3$ PUFA equivalents was also calculated as the sum of LC $n-3$ PUFA and 0.33 of the SDA content. This assumes that human subjects consuming these poultry tissues would convert $33 \%$ of the SDA to LC $n-3$ PUFA $^{(18)}$. Some caution should be applied to these figures as it seems likely that this is an overestimate of the conversion efficiency as the birds in this experiment appeared to be much less efficient at converting SDA to LC $n-3$ PUFA (see below), and it seems unlikely that birds would be so much less efficient than human subjects in this respect. 
Table 7. Effect of the diets on the fat content and fatty acid composition ( $\mathrm{mg} / 100 \mathrm{~g}$ fresh tissue) of skinless leg meat (Mean values with their standard errors)

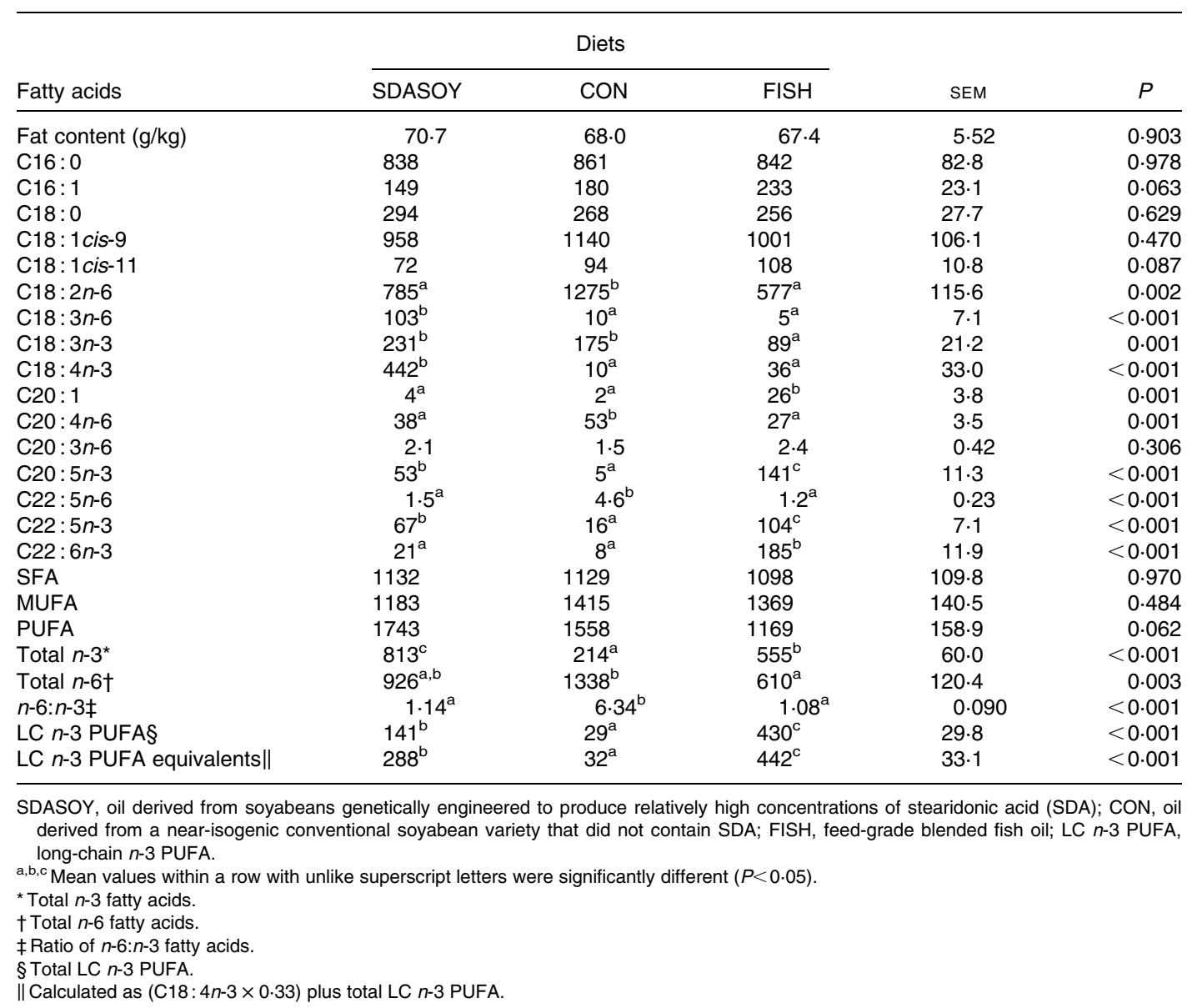

The concentration of LC $n$-3 PUFA equivalents was still greatest when birds were fed FISH (although this was not significant in the skinless breast meat), but the difference between SDASOY and CON tissues was more marked. If the estimate of $33 \%$ for the conversion efficiency of SDA to LC $n$-3 PUFA in human subjects is correct, then a $100 \mathrm{~g}$ serving of breast and leg meat with skin from birds fed SDASOY would provide 69 and $111 \%$ of LC $n-3$ PUFA equivalents. Total $n-6$ PUFA content was greatest in birds fed CON, although birds fed SDASOY had higher concentrations of total $n$-6 PUFA compared with those fed FISH (except in the skinless leg meat). The ratio of $n-6: n-3$ fatty acids was greatest in tissues from birds fed CON.

\section{Pool sizes of fatty acids}

The intake (over the grower and finisher period) and edible tissue pool size (sum of breast meat, leg meat, breast skin and leg skin) of fatty acids for the different diets are summarised in Table 11. Birds fed CON accumulated some SDA and LC $n$-3 PUFA, despite having no detectable amounts of these fatty acids in their diet.

\section{Sensory analysis}

The results of the sensory analysis are summarised in Tables 12 and 13. Differences that were perceived in the breast meats were associated with the texture and appearance of the meat, but not its flavour, aroma or aftertaste. There were no significant differences between the leg meats in terms of their appearance and texture. However, significant differences were perceived between the leg meats in terms of their aroma, flavour and aftertaste, especially among those that had been reheated. Reheating the meats reduced their meaty aroma. Reheated meat from birds fed FISH had significantly less chicken flavour than the other meats, and significantly less degree of roast aroma than the other meats apart from the reheated SDASOY meat. The fish aroma and flavour were stronger in the meat from birds fed FISH (both when the meat was freshly cooked and when it was reheated). Reheated meat from birds fed SDASOY also had a stronger fishy aroma and flavour than meat from birds fed CON, although these fishy notes were not as marked as in the meat from birds fed FISH. The oily aroma of meat from birds fed SDASOY and FISH was also stronger than that from birds fed CON (when the meat was both freshly cooked and 
Table 8. Effect of the diets on the fat content and fatty acid composition ( $\mathrm{mg} / 100 \mathrm{~g}$ fresh tissue) of skin (Mean values with their standard errors)

\begin{tabular}{|c|c|c|c|c|c|}
\hline \multirow[b]{2}{*}{ Fatty acids } & \multicolumn{3}{|c|}{ Diets } & \multirow[b]{2}{*}{ SEM } & \multirow[b]{2}{*}{$P$} \\
\hline & SDASOY & CON & FISH & & \\
\hline Fat content $(\mathrm{g} / \mathrm{kg})$ & $465^{a, b}$ & $481^{\mathrm{b}}$ & $422^{a}$ & $15 \cdot 0$ & 0.039 \\
\hline C16:0 & $6627^{\mathrm{a}, \mathrm{b}}$ & $8111^{\mathrm{b}}$ & $6163^{a}$ & 433.0 & 0.017 \\
\hline C16:1 & $1237^{\mathrm{a}}$ & $1717^{\mathrm{b}}$ & $1776^{\mathrm{b}}$ & 89.1 & 0.001 \\
\hline C18:0 & $2038^{a, b}$ & $2225^{\mathrm{b}}$ & $1661^{a}$ & $136 \cdot 8$ & 0.033 \\
\hline C18: 1 cis-9 & $8176^{\mathrm{a}}$ & $11757^{\mathrm{b}}$ & $7060^{\mathrm{a}}$ & $734 \cdot 2$ & 0.001 \\
\hline C18: 1 cis-11 & $539^{a}$ & $859^{\mathrm{b}}$ & $740^{\mathrm{b}}$ & 47.9 & 0.001 \\
\hline C18:2n-6 & $5963^{a}$ & $11795^{b}$ & $4217^{\mathrm{a}}$ & $626 \cdot 6$ & $<0.001$ \\
\hline$C 18: 3 n-6$ & $852^{\mathrm{b}}$ & $91^{\mathrm{a}}$ & $46^{\mathrm{a}}$ & $24 \cdot 2$ & $<0.001$ \\
\hline$C 18: 3 n-3$ & $1837^{\mathrm{b}}$ & $1693^{b}$ & $683^{a}$ & $104 \cdot 8$ & $<0.001$ \\
\hline C18:4n-3 & $3673^{b}$ & $111^{a}$ & $286^{a}$ & $90 \cdot 4$ & $<0.001$ \\
\hline C20: 1 & 162 & 40 & 155 & $55 \cdot 6$ & 0.252 \\
\hline $\mathrm{C} 20: 4 n-6$ & 12 & 124 & 110 & 11.6 & 0.638 \\
\hline $\mathrm{C} 20: 3 n-6$ & 7 & 18 & 15 & $6 \cdot 4$ & 0.485 \\
\hline $\mathrm{C} 20: 5 n-3$ & $317^{\mathrm{b}}$ & $31^{\mathrm{a}}$ & $1058^{\mathrm{C}}$ & 30.5 & $<0.001$ \\
\hline $\mathrm{C} 22: 5 n-6$ & $3 \cdot 6^{a}$ & $7 \cdot 0^{\mathrm{b}}$ & $6 \cdot 1^{\mathrm{a}, \mathrm{b}}$ & 0.92 & 0.048 \\
\hline $\mathrm{C} 22: 5 n-3$ & $284^{\mathrm{b}}$ & $47^{\mathrm{a}}$ & $585^{c}$ & $19 \cdot 2$ & $<0.001$ \\
\hline $\mathrm{C} 22: 6 n-3$ & $78^{\mathrm{a}}$ & $21^{\mathrm{a}}$ & $921^{b}$ & 31.4 & $<0.001$ \\
\hline SFA & $8665^{a, b}$ & $10336^{\mathrm{b}}$ & $7825^{\mathrm{a}}$ & 566.9 & 0.022 \\
\hline MUFA & $10114^{\mathrm{a}, \mathrm{b}}$ & $14372^{\mathrm{b}}$ & $9730^{a}$ & 874.9 & 0.004 \\
\hline PUFA & $13127^{b}$ & $13940^{\mathrm{b}}$ & $7928^{a}$ & $802 \cdot 2$ & $<0.001$ \\
\hline Total $n-3^{*}$ & $6190^{\circ}$ & $1904^{\mathrm{a}}$ & $3533^{b}$ & 179.4 & $<0.001$ \\
\hline Total $n-6 \dagger$ & $6925^{\mathrm{b}}$ & $12011^{c}$ & $4374^{\mathrm{a}}$ & $649 \cdot 3$ & $<0.001$ \\
\hline$n-6: n-3 \ddagger$ & $1 \cdot 1^{\mathrm{a}}$ & $6 \cdot 3^{b}$ & $1 \cdot 2^{\mathrm{a}}$ & 0.06 & $<0.001$ \\
\hline LC $n-3$ PUFA§ & $680^{\mathrm{b}}$ & $99^{a}$ & $2564^{c}$ & $79 \cdot 2$ & $<0.001$ \\
\hline LC $n$-3 PUFA equivalents $\|$ & $1904^{\mathrm{b}}$ & $137^{\mathrm{a}}$ & $2659^{c}$ & $76 \cdot 7$ & $<0.001$ \\
\hline $\begin{array}{l}\text { SDASOY, oil derived from soy } \\
\text { CON, oil derived from a near } \\
\text { LC } n-3 \text { PUFA, long-chain } n-3 \\
\text { a,b,c Mean values within a row wi } \\
{ }^{*} \text { Total } n-3 \text { fatty acids. } \\
\text { † Total } n-6 \text { fatty acids. } \\
\text { † Ratio of } n-6: n-3 \text { fatty acids. } \\
\text { § Total LC } n-3 \text { PUFA. } \\
\text { |l Calculated as (C18: } 4 n-3 \times 0.3\end{array}$ & $\begin{array}{l}\text { genetically en } \\
\text { conventiona } \\
\text { superscript }\end{array}$ & $\begin{array}{l}\text { d to produce } \\
\text { ean variety th } \\
\text { ere significant }\end{array}$ & $\begin{array}{l}\text { ly high conce } \\
\text { ot contain SD } \\
\text { ent }(P<0.05) \text {. }\end{array}$ & $\begin{array}{l}\text { s of stear } \\
\text { feed-grac }\end{array}$ & $\begin{array}{l}\text { id (SDA); } \\
\text { ed fish oil; }\end{array}$ \\
\hline
\end{tabular}

reheated). Although there was no difference in the freshly cooked meats, the chicken flavour and the degree of roast aftertaste were significantly lower in the reheated SDASOY and FISH meats compared with the CON meats. Reheated meat from birds fed FISH had a significantly higher oily aftertaste than the other meats. Reheated meat from birds fed SDASOY and FISH had a significantly higher oily mouthfeel than reheated meat from birds fed CON. Birds fed FISH also had a significantly higher fishy aftertaste than birds fed CON and SDASOY, when the meat was both freshly cooked and reheated. The reheated SDASOY meat also had a significantly higher fishy aftertaste than the reheated CON meat, but it was much less marked than the fishy aftertaste of the FISH meat.

\section{Discussion}

The $n-3$ (and C18:3n-6) PUFA concentrations of the diets largely reflected the composition of the oils used in their manufacture, whereas the C18:2n-6 concentration of the diets was generally greater than would have been expected, suggesting that the other feed ingredients used in the diet contributed relatively large amounts of $\mathrm{C} 18: 2$ but virtually no $n-3$ fatty acids. Some traces of C18:3n-6 must have been present in other feeds, as all diets contained some C18:3n-6, although this fatty acid was undetectable in CON.

The performance of the birds was within the expected range of the breed standard ${ }^{(17)}$, and so the study did replicate commercial performance. Feeding SDASOY had no effect on bird performance or carcass composition. Compared with the birds fed CON or SDASOY, the birds fed fish oil (FISH) did not produce as much saleable meat, which was largely a reflection of their reduced intake of feed.

Although birds fed the CON diet consumed over $17 \mathrm{~g}$ of LNA each, this did not result in the accumulation of LC $n-3$ PUFA in the edible tissues to any nutritionally meaningful extent, which is in accordance with the findings of both López-Ferrer et al. ${ }^{(12)}$ and Rymer \& Givens ${ }^{(7)}$. However, since the CON diet contained no detectable amounts of SDA or LC $n-3$ PUFA, the (limited) accumulation of these fatty acids in the edible tissues must have come from the desaturation and elongation of dietary LNA. The accumulation of SDA, EPA, DPA and DHA in the edible tissues of CON birds accounted for $1 \cdot 3,0.9,1 \cdot 3$ and $0.8 \%$, respectively, of dietary LNA consumed. Replacing soya oil (CON or SDASOY) with FISH, as expected, significantly increased 
Table 9. Effect of diets on the fat content and fatty acid composition ( $\mathrm{mg} / 100 \mathrm{~g}$ fresh tissue) of breast meat with skin (Mean values with their standard errors)

\begin{tabular}{|c|c|c|c|c|c|}
\hline \multirow[b]{2}{*}{ Fatty acids } & \multicolumn{3}{|c|}{ Diets } & \multirow[b]{2}{*}{ SEM } & \multirow[b]{2}{*}{$P$} \\
\hline & SDASOY & CON & $\mathrm{FISH}$ & & \\
\hline Fat content $(\mathrm{g} / \mathrm{kg})$ & $75 \cdot 4^{a, b}$ & $78 \cdot 8^{b}$ & $65 \cdot 4^{a}$ & $2 \cdot 88$ & 0.014 \\
\hline C16:0 & $983^{a, b}$ & $1115^{\mathrm{b}}$ & $877^{a}$ & $59 \cdot 2$ & 0.040 \\
\hline C16: 1 & $163^{a}$ & $219^{b}$ & $231^{\mathrm{b}}$ & $13 \cdot 0$ & 0.005 \\
\hline C18:0 & $327^{\mathrm{b}}$ & $335^{b}$ & $260^{a}$ & $17 \cdot 4$ & 0.017 \\
\hline C18: 1cis-9 & $1149^{a}$ & $1571^{\mathrm{b}}$ & $1001^{a}$ & $80 \cdot 1$ & 0.001 \\
\hline C18: 1 cis-11 & $81^{a}$ & $122^{b}$ & $110^{b}$ & $5 \cdot 8$ & 0.001 \\
\hline C18:2n-6 & $867^{a}$ & $1624^{\mathrm{b}}$ & $584^{a}$ & $77 \cdot 8$ & $<0.001$ \\
\hline$C 18: 3 n-6$ & $121^{b}$ & $11^{a}$ & $6^{a}$ & $3 \cdot 1$ & $<0.001$ \\
\hline$C 18: 3 n-3$ & $262^{b}$ & $223^{b}$ & $90^{\mathrm{a}}$ & $12 \cdot 8$ & $<0.001$ \\
\hline C18:4n-3 & $522^{b}$ & $13^{a}$ & $37^{a}$ & 14.4 & $<0.001$ \\
\hline $\mathrm{C} 20: 1$ & $15^{a, b}$ & $6^{a}$ & $24^{b}$ & $4 \cdot 7$ & 0.046 \\
\hline $\mathrm{C} 20: 4 n-6$ & $31^{\mathrm{b}}$ & $40^{c}$ & $22^{a}$ & $2 \cdot 0$ & $<0.001$ \\
\hline $\mathrm{C} 20: 3 n-6$ & $8^{a, b}$ & $15^{b}$ & $3^{a}$ & 2.9 & 0.039 \\
\hline $\mathrm{C} 20: 5 n-3$ & $53^{b}$ & $13^{a}$ & $140^{c}$ & 8.4 & $<0.001$ \\
\hline $\mathrm{C} 22: 5 n-6$ & $1 \cdot 1^{\mathrm{a}}$ & $3 \cdot 4^{b}$ & $1 \cdot 0^{\mathrm{a}}$ & 0.19 & $<0.001$ \\
\hline $\mathrm{C} 22: 5 n-3$ & $65^{\mathrm{b}}$ & $15^{a}$ & $101^{c}$ & 3.5 & $<0.001$ \\
\hline $\mathrm{C} 22: 6 n-3$ & $19^{a}$ & $9^{a}$ & $181^{\mathrm{b}}$ & 4.4 & $<0.001$ \\
\hline SFA & $1310^{a, b}$ & $1450^{b}$ & $1137^{a}$ & $75 \cdot 8$ & 0.035 \\
\hline MUFA & $1408^{a}$ & $1947^{b}$ & $1367^{\mathrm{a}}$ & $97 \cdot 9$ & 0.002 \\
\hline PUFA & $1950^{\mathrm{b}}$ & $1967^{\mathrm{b}}$ & $1167^{\mathrm{a}}$ & $105 \cdot 8$ & $<0.001$ \\
\hline Total $n-3^{*}$ & $922^{c}$ & $273^{a}$ & $550^{\mathrm{b}}$ & 31.9 & $<0.001$ \\
\hline Total $n-6 \dagger$ & $1019^{b}$ & $1676^{c}$ & $613^{a}$ & $80 \cdot 2$ & $<0.001$ \\
\hline$n-6: n-3 \ddagger$ & $1 \cdot 11^{\mathrm{a}}$ & $6 \cdot 18^{b}$ & $1 \cdot 12^{\mathrm{a}}$ & 0.061 & $<0.001$ \\
\hline LC $n$-3 PUFA§ & $137^{\mathrm{b}}$ & $37^{a}$ & $422^{c}$ & $14 \cdot 1$ & $<0.001$ \\
\hline LC $n$-3 PUFA equivalents\| & $311^{\mathrm{b}}$ & $41^{\mathrm{a}}$ & $435^{c}$ & $16 \cdot 0$ & $<0.001$ \\
\hline \multicolumn{6}{|c|}{$\begin{array}{l}\text { SDASOY, oil derived from soyabeans genetically engineere } \\
\text { derived from a near-isogenic conventional soyabean varie } \\
\text { long-chain } n \text {-3 PUFA. } \\
\text { a,b,c Mean values within a row with unlike superscript letters } \\
{ }^{*} \text { Total } n-3 \text { fatty acids. } \\
\text { † Total } n-6 \text { fatty acids. } \\
\text { † Ratio of } n-6: n-3 \text { fatty acids. } \\
\S \text { Total LC } n \text {-3 PUFA. } \\
\| \text { Calculated as (C18: } 4 n-3 \times 0.33 \text { ) plus total LC } n-3 \text { PUFA. }\end{array}$} \\
\hline
\end{tabular}

the tissue concentration of LC $n-3$ PUFA. This was because of the dietary supply of preformed LC $n-3$ PUFA, and this approach to enriching poultry meat with LC $n$-3 PUFA has been well reported ${ }^{(3-8)}$. With SDASOY, an increase in the LC $n-3$ PUFA content of the tissues was observed, although not to the same extent as was observed with FISH. If it is assumed that the LNA consumed by birds fed either CON or SDASOY was converted with equal efficiency, and that any other deposited SDA and LC $n-3$ PUFA in tissues from birds fed SDASOY was derived from dietary SDA, then dietary SDA accounted for the accumulation of 9389, 798, 870 and $173 \mathrm{mg}$ of SDA, EPA, DPA and DHA, respectively. This accumulation accounts for $18.33,1.56,1.70$ and $0.34 \%$ of the SDA consumed by birds fed SDASOY. The conversion of LNA to SDA was probably somewhat inhibited by the dietary supply of SDA, but even if the contribution of LNA to SDA and LC $n-3$ PUFA is assumed to be zero, the conversion and accumulation efficiency of SDA to EPA, DPA and DHA is only $1 \cdot 9,2 \cdot 2$ and $0.6 \%$, respectively. The conversion (and accumulation in the edible tissues) efficiency of SDA to LC $n-3$ PUFA does not therefore appear to be very different from that of LNA.
The accumulation of SDA in the birds' tissues appears to be in contrast to the metabolism of SDA by human subjects $^{(18)}$. Human subjects do not appear to accumulate SDA in their tissues ${ }^{(18,19)}$, but the birds in this experiment and that reported by Kitessa \& Young ${ }^{(14)}$ did accumulate considerable amounts of SDA. This accumulation of dietary SDA has also been observed in fish ${ }^{(20,21)}$. Approximately, $19 \%$ of the SDA consumed accumulated in the edible tissues (breast muscle, leg muscle and skin from the breast and leg). In the case of birds fed SDASOY, this amounted to 509 and $838 \mathrm{mg} / 100 \mathrm{~g}$ in the breast and leg meat (with skin), respectively. James et al. ${ }^{(18)}$ suggested that $3 \mathrm{~g}$ SDA was, in human subjects, equivalent to $1 \mathrm{~g}$ EPA. On this basis, the SDA accumulated in the breast and leg meat (with skin) of SDASOY-fed birds would supply the equivalent of an additional 170 and $279 \mathrm{mg}$ LC $n-3$ PUFA/100 g meat, respectively. Even in the much less lipid-rich tissues of skinless breast and leg meat, the potential contribution from SDA from birds fed SDASOY would provide the equivalent of 164 and $288 \mathrm{mg}$ LC $n-3$ PUFA/ $100 \mathrm{~g}$ meat, respectively, if the estimate of James et al. ${ }^{(18)}$ is correct.

The amount of SDA that could be fed to birds in the present study (approximately $51 \mathrm{~g}$ over a mean $32 \mathrm{~d}$ feeding 
Table 10. Effect of diets on the fat content and fatty acid composition ( $\mathrm{mg} / 100 \mathrm{~g}$ fresh tissue) of leg meat with skin (Mean values with their standard errors)

\begin{tabular}{|c|c|c|c|c|c|}
\hline \multirow[b]{2}{*}{ Fatty acids } & \multicolumn{3}{|c|}{ Diets } & \multirow[b]{2}{*}{ SEM } & \multirow[b]{2}{*}{$P$} \\
\hline & SDASOY & $\mathrm{CON}$ & FISH & & \\
\hline Fat content $(\mathrm{g} / \mathrm{kg})$ & 122 & 121 & 113 & 4.9 & 0.354 \\
\hline C16:0 & $1590^{a b}$ & $1800^{\mathrm{b}}$ & $1521^{a}$ & 71.8 & 0.040 \\
\hline $\mathrm{C} 16: 1$ & $291^{\mathrm{a}}$ & $379^{b}$ & $430^{\mathrm{b}}$ & $18 \cdot 9$ & $<0.001$ \\
\hline C18:0 & 521 & 522 & 435 & $25 \cdot 2$ & 0.045 \\
\hline C18: 1 cis-9 & $1895^{a}$ & $2514^{b}$ & $1779^{a}$ & 81.5 & $<0.001$ \\
\hline C18:1 cis-11 & $132^{\mathrm{a}}$ & $193^{b}$ & $189^{b}$ & $9 \cdot 3$ & 0.001 \\
\hline $\mathrm{C} 18: 2 n-6$ & $1457^{b}$ & $2637^{c}$ & $1042^{a}$ & $95 \cdot 7$ & $<0.001$ \\
\hline C18:3n-6 & $200^{\mathrm{b}}$ & $21^{\mathrm{a}}$ & $11^{\mathrm{a}}$ & $6 \cdot 4$ & $<0.001$ \\
\hline C18: $3 n-3$ & $440^{\mathrm{b}}$ & $372^{\mathrm{b}}$ & $165^{a}$ & $19 \cdot 3$ & $<0.001$ \\
\hline C18: $4 n-3$ & $861^{\mathrm{b}}$ & $23^{\mathrm{a}}$ & $68^{\mathrm{a}}$ & $30 \cdot 1$ & $<0.001$ \\
\hline C20: 1 & $24^{\mathrm{a}, \mathrm{b}}$ & $7^{\mathrm{a}}$ & $43^{b}$ & $6 \cdot 7$ & 0.008 \\
\hline $\mathrm{C} 20: 4 n-6$ & $48^{a, b}$ & $62^{\mathrm{b}}$ & $38^{\mathrm{a}}$ & $3 \cdot 0$ & $<0.001$ \\
\hline C20:3n-6 & $2 \cdot 8$ & 3.6 & 4.0 & 0.92 & 0.663 \\
\hline C20: $5 n-3$ & $87^{\mathrm{b}}$ & $9^{a}$ & $258^{\mathrm{c}}$ & 7.5 & $<0.001$ \\
\hline $\mathrm{C} 22: 5 n-6$ & $1.8^{\mathrm{a}}$ & $4.9^{\mathrm{b}}$ & $1.9^{\mathrm{a}}$ & 0.21 & $<0.001$ \\
\hline $\mathrm{C} 22: 5 n-3$ & $95^{\mathrm{b}}$ & $20^{a}$ & $165^{\mathrm{c}}$ & $5 \cdot 0$ & $<0.001$ \\
\hline $\mathrm{C} 22: 6 n-3$ & $29^{a}$ & $10^{\mathrm{a}}$ & $278^{\mathrm{b}}$ & 8.4 & $<0.001$ \\
\hline SFA & $2111^{a, b}$ & $2322^{b}$ & $1956^{a}$ & $95 \cdot 8$ & 0.052 \\
\hline MUFA & $2342^{a}$ & $3092^{b}$ & $2441^{a}$ & $101 \cdot 1$ & $<0.001$ \\
\hline PUFA & $3221^{b}$ & $3161^{b}$ & $2030^{a}$ & 138.6 & $<0.001$ \\
\hline Total $n-3^{*}$ & $1512^{\mathrm{c}}$ & $433^{a}$ & $934^{\mathrm{b}}$ & $52 \cdot 1$ & $<0.001$ \\
\hline Total $n-6 \dagger$ & $1705^{\mathrm{b}}$ & $2720^{c}$ & $1090^{a}$ & $100 \cdot 8$ & $<0.001$ \\
\hline$n-6: n-3 \ddagger$ & $1 \cdot 13^{a}$ & $6 \cdot 30^{b}$ & $1 \cdot 17^{\mathrm{a}}$ & 0.056 & $<0.001$ \\
\hline LC $n-3$ PUFA§ & $211^{b}$ & $38^{a}$ & $701^{\mathrm{c}}$ & $20 \cdot 4$ & $<0.001$ \\
\hline LC $n$-3 PUFA equivalents\| & $498^{\mathrm{b}}$ & $46^{\mathrm{a}}$ & $724^{c}$ & 23.9 & $<0.001$ \\
\hline \multicolumn{6}{|c|}{$\begin{array}{l}\text { SDASOY, oil derived from soyabeans genetically engineered to produce relatively high concentrations of stearidonic acid (SDA); } \\
\text { CON, oil derived from a near-isogenic conventional soyabean variety that did not contain SDA; FISH, feed-grade blended fish oil; } \\
\text { LC } n-3 \text { PUFA, long-chain } n-3 \text { PUFA. }\end{array}$} \\
\hline \multirow{2}{*}{\multicolumn{6}{|c|}{ 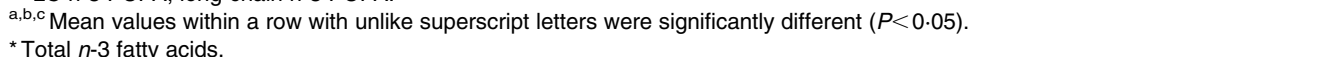 }} \\
\hline & & & & & \\
\hline \multicolumn{6}{|c|}{ *Total $n-3$ fatty acids. } \\
\hline \multicolumn{6}{|l|}{$\begin{array}{l}\text { †Total } n-6 \text { fatty acids. } \\
\text { ¥ Ratio of } n-6: n-3 \text { fatty acids. }\end{array}$} \\
\hline $\begin{array}{l}\text { § Total LC } n-3 \text { PUFA. } \\
\text { II Calculated as (C18: } 4 n-3 \times 0 .\end{array}$ & & & & & \\
\hline
\end{tabular}

period) was much greater than that could be achieved by Kitessa \& Young ${ }^{(14)}$ when they fed echium oil (approximately $15 \mathrm{~g}$ over a $34 \mathrm{~d}$ feeding period). The inclusion rate of oil was higher in the present study compared with that of Kitessa \& Young ${ }^{(14)}$, but SDASOY was also a much richer source of SDA (approximately 24\%) than echium oil (approximately 12\%). The large amount of SDA that was fed in the present study when SDASOY was fed did mean that there was a significant increase in the pool size of LC $n-3$ PUFA in the meat and skin of SDASOY-fed birds compared with CON. The amount of LC $n$-3 PUFA supplied in $100 \mathrm{~g}$ of either breast or

Table 11. Effect of the diets on the intake and pool sizes of $n-3$ fatty acids

(Mean values with their standard errors)

\begin{tabular}{|c|c|c|c|c|c|}
\hline \multirow[b]{2}{*}{ Fatty acids } & \multicolumn{3}{|c|}{ Diets } & \multirow[b]{2}{*}{ SEM } & \multirow[b]{2}{*}{$P$} \\
\hline & SDASOY & CON & $\mathrm{FISH}$ & & \\
\hline \multicolumn{6}{|c|}{ Intake of $n-3$ fatty acids (mg/bird) } \\
\hline C18:3 & $19717^{b}$ & $17393^{\mathrm{b}}$ & $6415^{a}$ & 628 & $<0.001$ \\
\hline C18:4 & $51219^{b}$ & $0^{a}$ & $3133^{a}$ & 2200 & $<0.001$ \\
\hline $\mathrm{C} 20: 5$ & $0^{\mathrm{a}}$ & $0^{\mathrm{a}}$ & $13724^{\mathrm{b}}$ & 536 & $<0.001$ \\
\hline C22: 5 & $7^{\mathrm{a}}$ & $3^{\mathrm{a}}$ & $4919^{\mathrm{b}}$ & 203 & $<0.001$ \\
\hline $\mathrm{C} 22: 6$ & $0^{\mathrm{a}}$ & $6^{a}$ & $13611^{b}$ & 559 & $<0.001$ \\
\hline \multicolumn{6}{|c|}{ Pool size (mg/bird) of fatty acids in edible tissues (sum of breast and leg meat with skin) } \\
\hline C18:3 & $4884^{\mathrm{C}}$ & $3840^{\mathrm{b}}$ & $1662^{a}$ & 235 & $<0.001$ \\
\hline C18: 4 & $9645^{\mathrm{b}}$ & $227^{a}$ & $690^{a}$ & 443 & $<0.001$ \\
\hline $\mathrm{C} 20: 5$ & $975^{\mathrm{b}}$ & $155^{\mathrm{a}}$ & $2627^{\mathrm{c}}$ & 149 & $<0.001$ \\
\hline C22: 5 & $1126^{b}$ & $234^{a}$ & $1777^{c}$ & 68 & $<0.001$ \\
\hline C22: 6 & $331^{a}$ & $131^{\mathrm{a}}$ & $3110^{b}$ & 136 & $<0.001$ \\
\hline
\end{tabular}

SDASOY, oil derived from soyabeans genetically engineered to produce relatively high concentrations of stearidonic acid (SDA); CON, oil derived from a near-isogenic conventional soyabean variety that did not contain SDA; FISH, feed-grade blended fish oil.

${ }^{a, b, c}$ Mean values within a row with unlike superscript letters were significantly different within a dataset $(P<0.05)$. 
Table 12. Effect of the diets on the sensory attributes (scores from 0 to 100) of freshly cooked breast meat

\begin{tabular}{|c|c|c|c|c|c|}
\hline \multirow[b]{2}{*}{ Attributes } & \multicolumn{3}{|c|}{ Poultry diets } & \multirow[b]{2}{*}{ LSD } & \multirow[b]{2}{*}{$P$} \\
\hline & SDASOY & CON & FISH & & \\
\hline Depth of colour & $48 \cdot 1^{a}$ & $44 \cdot 2^{\mathrm{a}}$ & $52 \cdot 9^{\mathrm{b}}$ & $4 \cdot 1$ & 0.0013 \\
\hline Texture & $48 \cdot 3^{\mathrm{a}, \mathrm{b}}$ & $44 \cdot 6^{\mathrm{a}}$ & $52 \cdot 1^{\mathrm{b}}$ & $5 \cdot 2$ & 0.0244 \\
\hline Moistness & $59 \cdot 3$ & $60 \cdot 7$ & $53 \cdot 2$ & $7 \cdot 1$ & 0.0915 \\
\hline \multicolumn{6}{|l|}{ Aroma attributes } \\
\hline Chicken & 54.8 & $55 \cdot 6$ & $56 \cdot 2$ & 5.0 & 0.8331 \\
\hline Degree of roast & $55 \cdot 6$ & 53.4 & 54.8 & 3.9 & 0.5083 \\
\hline Meaty & 58.4 & $53 \cdot 7$ & $60 \cdot 1$ & 7.5 & 0.2100 \\
\hline \multicolumn{6}{|l|}{ Texture attributes } \\
\hline Hardness & $44 \cdot 5^{a}$ & $54 \cdot 0^{\mathrm{b}}$ & $41 \cdot 3^{\mathrm{a}}$ & $9 \cdot 2$ & 0.0254 \\
\hline Fibrousness & 59.5 & 58.4 & 58.9 & $5 \cdot 3$ & 0.8987 \\
\hline Moistness & 46.9 & $48 \cdot 2$ & $49 \cdot 0$ & $7 \cdot 0$ & 0.8187 \\
\hline Cohesive & $46 \cdot 1$ & $50 \cdot 4$ & 48.6 & 8.8 & 0.6052 \\
\hline \multicolumn{6}{|l|}{ Flavour attributes } \\
\hline Chicken & $51 \cdot 3$ & $53 \cdot 2$ & $52 \cdot 8$ & 5.4 & 0.7584 \\
\hline Degree of roast & $50 \cdot 6$ & $51 \cdot 0$ & $50 \cdot 7$ & 4.9 & 0.9807 \\
\hline Salt & 10.5 & 9.2 & $9 \cdot 4$ & $2 \cdot 7$ & 0.5716 \\
\hline Sweet & $9 \cdot 8$ & 9.0 & 9.2 & 2.5 & 0.7829 \\
\hline Meaty & 51.9 & 45.4 & 52.5 & 7.8 & 0.1347 \\
\hline \multicolumn{6}{|l|}{ Aftertaste attributes } \\
\hline Chicken & $45 \cdot 9$ & $45 \cdot 7$ & $43 \cdot 4$ & $6 \cdot 8$ & 0.6900 \\
\hline Degree of roast & 39.9 & $43 \cdot 1$ & $36 \cdot 0$ & $6 \cdot 6$ & 0.1004 \\
\hline Salt & $10 \cdot 3$ & 8.6 & 8.4 & 3.2 & 0.3978 \\
\hline Sweet & 9.6 & 8.5 & 8.9 & $2 \cdot 1$ & 0.5433 \\
\hline
\end{tabular}

SDASOY, oil derived from soyabeans genetically engineered to produce relatively high concentrations of stearidonic acid (SDA); CON, oil derived from a near-isogenic conventional soyabean variety that did not contain SDA; FISH, feed-grade blended fish oil; LSD, least significant difference. ${ }^{\mathrm{a}, \mathrm{b}}$ Mean values within a row with unlike superscript letters were significantly different $(P<0 \cdot 05)$.

leg meat (with skin) from birds fed SDASOY would meet 30 or $47 \%$, respectively, of the UK minimum daily recommended intake ${ }^{(1)}$, while skinless breast or leg meat would provide 19 or $31 \%$. In the study reported by Kitessa \& Young ${ }^{(14)}$, the skinless breast and leg meat that was produced would supply 2 and $30 \%$ of the daily recommended intake of $450 \mathrm{mg}$. The difference in accumulation of LC $n-3$ PUFA between these two studies was particularly marked in the leaner skinless breast meat.

The composition of LC $n$ - 3 PUFA in the broiler tissues was affected by the diet. While up to $43 \%$ of the LC $n-3$ PUFA in the meat (with skin) from birds fed FISH was DHA, the corresponding estimate for CON was $26 \%$ and for SDASOY was $14 \%$. DPA, on the other hand, accounted for up to $47 \%$ of the LC $n-3$ PUFA in birds fed SDASOY, but it accounted for only $24 \%$ in birds fed FISH. The lack of accumulation of DHA in poultry tissues in response to feeding SDA was also observed by Kitessa \& Young ${ }^{(14)}$, but the accumulation of DPA in addition to EPA may be of nutritional significance. The consumption of meat rather than fish results in an increased consumption of $\mathrm{DPA}^{(22)}$, but the implications of this for cardiovascular health are not clear. There is some evidence that DPA is more beneficial than EPA in protecting against peripheral arterial disease ${ }^{(23)}$ and that a higher plasma concentration of DPA (but not DHA) was associated with a lower risk of non-fatal myocardial infarction $^{(24)}$. Short-term supplementation with DPA in rats was observed to increase the concentration of DHA in the liver, and the concentration of EPA in the liver, heart and skeletal muscle ${ }^{(25)}$. However, the relative merits of consuming chicken meat enriched with DPA rather than DHA (or not enriched with any LC $n-3$ PUFA) need to be evaluated.

\section{Sensory qualities}

The great advantage of the meat from SDA birds compared with that from FISH birds was its improved sensory attributes, although this was largely because of the lower LC $n-3$ PUFA content of the SDA meat. The negative impact of fish oil in the poultry diet on the sensory characteristics of poultry meat is well documented ${ }^{(26,27)}$, particularly when the meat is cooked, refrigerated and then reheated ${ }^{(15,28)}$. The fishy notes detectable in the meat from birds fed fish oil can be partly overcome by supplementing the diet with antioxidants such as vitamin $\mathrm{E}^{(29)}$, but even at relatively high doses (in excess of $100 \mathrm{mg} \mathrm{DL}-\alpha$-tocopherol $/ \mathrm{kg}$ ), fishy flavours may still be detected when the meat has been reheated ${ }^{(30)}$. Although the aroma, flavour and aftertaste of skinless, freshly cooked breast meat were not significantly affected by dietary treatment, the same was not the case for the more lipid-rich leg meat. Differences that were perceived in the attributes of the breast meat were related more to birds fed CON, but were because of perceived textural differences. This may be a consequence of differences in the melting points of different fatty acids, and the differences in fatty acid profiles (notably the higher concentration of $\mathrm{C} 18: 2 n-6$ in the CON meat) affecting the meat's texture. 
Table 13. Effect of the diets on the sensory attributes (scores from 0 to 100) of freshly cooked and reheated leg meat

\begin{tabular}{|c|c|c|c|c|c|c|c|c|}
\hline \multirow[b]{2}{*}{ Attributes } & \multicolumn{3}{|c|}{ Freshly cooked meat } & \multicolumn{3}{|c|}{ Reheated meat } & \multirow[b]{2}{*}{ LSD } & \multirow[b]{2}{*}{$P$} \\
\hline & SDASOY & $\mathrm{CON}$ & FISH & SDASOY & $\mathrm{CON}$ & $\mathrm{FISH}$ & & \\
\hline \multicolumn{9}{|c|}{ Appearance attributes } \\
\hline Depth of colour & $53 \cdot 1$ & 54.9 & $54 \cdot 0$ & 57.9 & $54 \cdot 8$ & $50 \cdot 2$ & 8.7 & 0.648 \\
\hline Texture & $50 \cdot 5$ & $53 \cdot 0$ & $51 \cdot 1$ & $49 \cdot 6$ & $56 \cdot 5$ & $51 \cdot 7$ & 9.4 & 0.737 \\
\hline \multicolumn{9}{|l|}{ Aroma attributes } \\
\hline Chicken & $46 \cdot 6^{\mathrm{b}}$ & $47 \cdot 8^{\mathrm{b}}$ & $42 \cdot 2^{b}$ & $41 \cdot 4^{\mathrm{b}}$ & $48 \cdot 3^{b}$ & $29 \cdot 9^{a}$ & $7 \cdot 3$ & $<0.001$ \\
\hline Degree of roast & $45 \cdot 4^{\mathrm{c}}$ & $46 \cdot 1^{\mathrm{c}}$ & $39 \cdot 6^{b, c}$ & $37 \cdot 1^{\mathrm{a}, \mathrm{b}}$ & $45 \cdot 5^{\mathrm{c}}$ & $30 \cdot 6^{a}$ & 8.0 & 0.001 \\
\hline Meaty & $36 \cdot 3^{a, b}$ & $42 \cdot 5^{\mathrm{b}}$ & $38 \cdot 2^{b}$ & $30 \cdot 3^{a}$ & $34 \cdot 1^{a, b}$ & $29 \cdot 1^{a}$ & $7 \cdot 8$ & 0.012 \\
\hline Fishy & $18 \cdot 3^{a, b}$ & $12 \cdot 7^{\mathrm{a}}$ & $29 \cdot 1^{c}$ & $23 \cdot 6^{\mathrm{b}, \mathrm{c}}$ & $9 \cdot 1^{\mathrm{a}}$ & $51 \cdot 5^{d}$ & $10 \cdot 7$ & $<0.001$ \\
\hline Oily & $31 \cdot 7^{b, c}$ & $22 \cdot 3^{\mathrm{a}}$ & $36 \cdot 5^{\mathrm{b}, \mathrm{c}, \mathrm{d}}$ & $38 \cdot 9^{c, d}$ & $27 \cdot 6^{a, b}$ & $42 \cdot 3^{d}$ & $9 \cdot 0$ & $<0.001$ \\
\hline \multicolumn{9}{|l|}{ Texture attributes } \\
\hline Hardness & $43 \cdot 8$ & 44.9 & $47 \cdot 2$ & $46 \cdot 2$ & $45 \cdot 3$ & $40 \cdot 3$ & $8 \cdot 3$ & 0.639 \\
\hline Fibrousness & 48.5 & $45 \cdot 8$ & $53 \cdot 8$ & $45 \cdot 9$ & 49.5 & $45 \cdot 0$ & $6 \cdot 2$ & 0.062 \\
\hline Cohesive & $46 \cdot 5$ & 41.4 & $48 \cdot 1$ & $42 \cdot 6$ & $47 \cdot 7$ & 41.5 & $6 \cdot 3$ & 0.094 \\
\hline \multicolumn{9}{|l|}{ Flavour attributes } \\
\hline Chicken & $44 \cdot 6^{\mathrm{b}}$ & $49 \cdot 2^{b}$ & $42 \cdot 7^{\mathrm{b}}$ & $42 \cdot 5^{\mathrm{b}}$ & $45 \cdot 5^{\mathrm{b}}$ & $31.5^{\mathrm{a}}$ & 8.0 & 0.002 \\
\hline Degree of roast & $41 \cdot 8^{\mathrm{b}, \mathrm{c}}$ & $49 \cdot 3^{C}$ & $41 \cdot 8^{\mathrm{b}, \mathrm{c}}$ & $35 \cdot 8^{a, b}$ & $43 \cdot 4^{b, c}$ & $29 \cdot 3^{a}$ & $8 \cdot 6$ & 0.001 \\
\hline Salt & $9 \cdot 3$ & $9 \cdot 3$ & $8 \cdot 8$ & $8 \cdot 7$ & 7.9 & $10 \cdot 4$ & $2 \cdot 5$ & 0.497 \\
\hline Meaty & 38.5 & $39 \cdot 6$ & 37.9 & 31.6 & $32 \cdot 4$ & 30.8 & 8.2 & 0.118 \\
\hline Fishy & $20 \cdot 1^{a, b}$ & $11 \cdot 8^{a, b}$ & $23 \cdot 0^{\mathrm{b}}$ & $29 \cdot 0^{\mathrm{b}}$ & $10 \cdot 7^{a}$ & $51 \cdot 3^{c}$ & $11 \cdot 2$ & $<0.001$ \\
\hline \multicolumn{9}{|l|}{ Aftertaste attributes } \\
\hline Chicken & $38 \cdot 6^{b, c}$ & $42 \cdot 1^{c}$ & $37 \cdot 0^{b, c}$ & $34 \cdot 6^{\mathrm{b}}$ & $42 \cdot 3^{c}$ & $27 \cdot 2^{a}$ & $7 \cdot 21$ & 0.001 \\
\hline Degree of roast & $32 \cdot 7^{\mathrm{b}, \mathrm{c}}$ & $39 \cdot 3^{c}$ & $33 \cdot 0^{b, c}$ & $29 \cdot 4^{a, b}$ & $38 \cdot 6^{c}$ & $23 \cdot 8^{a}$ & $7 \cdot 3$ & 0.001 \\
\hline Salt & 8.5 & $11 \cdot 0$ & $8 \cdot 6$ & $8 \cdot 2$ & $7 \cdot 7$ & $9 \cdot 4$ & $2 \cdot 6$ & 0.177 \\
\hline Sweet & $7 \cdot 0$ & $8 \cdot 3$ & $7 \cdot 3$ & $6 \cdot 6$ & $7 \cdot 3$ & $6 \cdot 1$ & $1 \cdot 3$ & 0.054 \\
\hline Meaty & 32.4 & 34.5 & 31.8 & $25 \cdot 6$ & $29 \cdot 1$ & $28 \cdot 7$ & $6 \cdot 2$ & 0.085 \\
\hline Oily taste & $31 \cdot 7^{\mathrm{a}}$ & $31 \cdot 9^{\mathrm{a}}$ & $34 \cdot 6^{\mathrm{a}}$ & $37 \cdot 7^{\mathrm{a}}$ & $31 \cdot 3^{a}$ & $45 \cdot 7^{b}$ & $7 \cdot 0$ & 0.001 \\
\hline Oily mouthfeel & $34.5^{\mathrm{a}}$ & $35 \cdot 9^{a, b}$ & $36 \cdot 5^{a, b}$ & $42 \cdot 5^{\mathrm{b}, \mathrm{c}}$ & $33 \cdot 8^{a}$ & $46 \cdot 0^{c}$ & $7 \cdot 7$ & 0.013 \\
\hline Fishy & $14 \cdot 5^{\mathrm{a}, \mathrm{b}, \mathrm{c}}$ & $12 \cdot 1^{a, b}$ & $22 \cdot 5^{\mathrm{c}}$ & $18 \cdot 8^{\mathrm{b}, \mathrm{c}}$ & $9 \cdot 2^{a}$ & $45 \cdot 9^{d}$ & 9.4 & $<0.001$ \\
\hline
\end{tabular}

SDASOY, oil derived from soyabeans genetically engineered to produce relatively high concentrations of stearidonic acid (SDA); CON, oil derived from a near-isogenic conventional soyabean variety that did not contain SDA; FISH, feed-grade blended fish oil; LSD, least significant difference. a,b,c,d Mean values within a row with unlike superscript letters were significantly different $(P<0.05)$.

The sensory attributes of the more lipid-rich leg meat, however, were significantly affected by the diet that the birds had been fed. Significant fishy aromas, flavours and aftertastes were perceived in both the freshly cooked and reheated meat, and these were most marked in the meat from birds fed FISH (which had the highest LC $n$-3 PUFA content). Although these fishy attributes were also detected in the meat from birds fed SDASOY, the scores were lower, as the LC $n-3$ PUFA content of the SDASOY meat was lower. In the freshly cooked SDASOY meat, fishy scores were not significantly different from the CON meat. The reheated SDASOY meat had a more fishy aroma and flavour than the reheated CON meat (but was not significantly different from the freshly cooked SDASOY meat), and its fishy aftertaste was not significantly different from the freshly cooked CON meat. The reheated FISH meat, on the other hand, had significantly higher scores for all three 'fishy' attributes (aroma, flavour and aftertaste). A major benefit of birds accumulating dietary SDA as SDA (rather than as LC $n$-3 PUFA) may therefore be the greater oxidative stability this confers to the meat because of the lower peroxidisability index ${ }^{(31)}$ of SDA compared with LC $n-3$ PUFA. Enriching meat by feeding FISH (and therefore accumulating LC $n-3$ PUFA), on the other hand, resulted in a much greater negative impact on the sensory qualities of the meat. Skinless meat was used in the sensory analysis, and it seems likely that fishy attributes would be more noticeable in the meat with skin because of its much higher lipid content. For such meat, more protection through increased concentrations of vitamin $\mathrm{E}$ in the broiler diet may be required (and effective), although this would need to be determined by further research.

\section{Conclusions}

Broilers fed the diets supplemented with oil from soyabeans genetically modified to produce relatively high concentrations of SDA produced meat with increased concentrations of SDA, EPA and DPA, but not DHA (except in the skinless breast meat). There was no evidence that birds converted SDA to LC $n$-3 PUFA any more efficiently than LNA, but the use of an SDA-containing oil derived from a genetically engineered soya plant enabled much higher doses of SDA to be fed than would be the case if existing conventional sources (such as echium) were used. Although feeding the SDA-rich oil to birds had some negative effects on the sensory quality of the meat, these effects were much less marked than when fish oil was fed to the birds because of the lower LC $n-3$ PUFA content of the meat from birds fed the SDA-rich oil. 


\section{Acknowledgements}

The present study was funded by Monsanto Company. We are grateful to Mr Colin Green for his assistance during the feeding experiment and slaughter of the birds, and to $\mathrm{Mr}$ Ron Brown for the analysis of the fatty acids. We are also grateful to Sensory Dimensions, for conducting the sensory analysis of the samples. C. R. designed the experiment, analysed the data and drafted the manuscript. G. F. H. oversaw the experiment. Both G. F. H. and D. I. G. helped with the design and analysis of the data. Neither C. R. nor D. I. G. has any conflict of interest to disclose. G. F. H. works for Monsanto Company, which funded the work.

\section{References}

1. Scientific Advisory Committee on Nutrition/Committee on Toxicity (2004) Advice on Fish Consumption: Benefits and Risks, pp. 3. London: TSO.

2. Gibbs RA, Rymer C \& Givens DI (2010) Long-chain n-3 PUFA: intakes in the UK and the potential of a chicken meat prototype to increase them. Proc Nutr Soc 69, 144-155.

3. Hulan HW, Ackman RG, Ratnayake WMN, et al. (1988) Omega-3 fatty acid levels and performance of broiler chickens fed redfish meal or redfish oil. Can J Anim Sci 68, 533-547.

4. López-Ferrer S, Baucells MD, Barroeta AC, et al. (2001) n-3 Enrichment of chicken meat. 1. Use of very long-chain fatty acids in chicken diets and their influence on meat quality: fish oil. Poult Sci 80, 741-752.

5. Komprda T, Zelenka J, Bakaj P, et al. (2002) Cholesterol and fatty acid content in meat of turkeys fed diets with sunflower, linseed or fish oil. Arch Geflügelk 67, 65-75.

6. Zanini SF, Torres CAA, Bragagnolo N, et al. (2004) Effect of oil sources and vitamin E levels in the diet on the composition of fatty acids in rooster thigh and chest meat. $J$ Sci Food Agric 84, 672-682.

7. Rymer C \& Givens DI (2006) Effect of species and genotype on the efficiency of enrichment of poultry meat with $n-3$ polyunsaturated fatty acids. Lipids 41, 445-451.

8. Mirghelenj SA, Golian A \& Taghizadeh V (2009) Enrichment of chicken meat with long chain omega-3 fatty acids through dietary fish oil. Res J Biol Sci 4, 604-608.

9. Mooney JW, Hirschler EM, Kennedy AK, et al. (1998) Lipid and flavour quality of stored breast meat from broilers fed marine algae. J Sci Food Agric 78, 134-140.

10. Rymer C \& Givens DI (2010) Comparison of algal and fish sources on the oxidative stability of poultry meat and its enrichment with omega-3 polyunsaturated fatty acids. Poult Sci 89, 150-159.

11. Food and Agriculture Organization (2006) State of World Aquaculture: 2006. FAO Fisheries Technical Paper no. 500. Rome: FAO.

12. López-Ferrer S, Baucells MD, Barroeta AC, et al. (2001) n-3 Enrichment of chicken meat. 2. Use of precursors of long-chain polyunsaturated fatty acids: linseed oil. Poult Sci 80, 753-761.

13. Mir M (2008) Echium oil: a valuable source of $n-3$ and $n-6$ fatty acids. OCL 15, 252-256.

14. Kitessa SM \& Young P (2009) Echium oil is better than rapeseed oil in enriching poultry meat with $n-3$ polyunsaturated fatty acids, including eicosapentaenoic acid and docosapentaenoic acid. Br J Nutr 101, 709-715.

15. O'Keefe SF, Proudfoot FG \& Ackman RG (1995) Lipid oxidation in meats of omega-3 fatty-acid enriched broiler chickens. Food Res Int 28, 417-424.

16. Stone H, Sidel JL, Oliver J, et al. (1974) Sensory evaluation by quantitative descriptive analysis. Food Technol 28, 24-34.

17. Aviagen (2007) Ross 308 Broiler Performance Objectives June 2007. http://aviagen.com/ss/assets/Tech_Center/Ross_ Broiler/Ross_308_Broiler_Performance_Objectives.pdf

18. James MJ, Ursin VM \& Cleland LG (2003) Metabolism of stearidonic acid in human subjects: comparison with the metabolism of other $n-3$ fatty acids. Am J Clin Nutr 77, 1140-1145.

19. Miles EA, Tapati B, Dooper MMBW, et al. (2004) The influence of different combinations of gamma-linolenic acid, stearidonic acid and EPA on immune function in healthy young male subjects. Br J Nutr 91, 893-903.

20. Bell JG, Strachan F, Good JE, et al. (2006) Effect of dietary echium oil on growth, fatty acid composition and metabolism, gill prostaglandin production and macrophage activity in Atlantic cod (Gadus morhua L.). Aquac Res 37, 606-617.

21. Miller MR, Nichols PD \& Carter CG (2007) Replacement of dietary fish oil for Atlantic salmon parr (Salmo salar L.) with a stearidonic acid containing oil has no effect on omega-3 long-chain polyunsaturated fatty acid concentrations. Comp Biochem Physiol B Biochem Mol Biol 146, 197-206.

22. Howe PH, Meyer BM, Record S, et al. (2006) Dietary intake of long-chain $\omega-3$ polyunsaturated fatty acids: contribution of meat sources. Nutrition 22, 47-53.

23. Leng GC, Horrobin DF, Fowkes FGR, et al. (1994) Plasma essential fatty acids, cigarette smoking, and dietary antioxidants in peripheral arterial disease, a population-based case-control study. Arterioscler Thromb 14, 471-478.

24. Sun Q, Ma J, Campos H, et al. (2008) Blood concentrations of individual long-chain $n-3$ fatty acids and risk of nonfatal myocardial infarction. Am J Clin Nutr 88, 216-223.

25. Kaur G, Begg DP, Barr D, et al. (2010) Short-term docosapentaaenoic acid (22:5n-3) supplementation increases tissue docosapentaenoic acid, DHA and EPA concentrations in rats. BrJ Nutr 103, 32-37.

26. Carrick CW \& Hauge SM (1926) The effect of cod-liver oil upon flavour in poultry meat. Poult Sci 5, 213-215.

27. Meynier A, Genot C \& Gandemer G (1999) Oxidation of muscle phospholipids in relation to their fatty acid composition with emphasis on volatile compounds. I Sci Food Agric 79, 797-804.

28. Wilson BR, Pearson AM \& Shorland FB (1976) Effect of total lipids and phospholipids on warmed-over flavor in red and white muscle from several species as measured by thiobarbituric acid analysis. J Agric Food Chem 24, 7-11.

29. Nam K-T, Lee H-A, Min B-S, et al. (1997) Influence of dietary supplementation with linseed and vitamin $\mathrm{E}$ on fatty acids, $\alpha$-tocopherol and lipid peroxidation in muscles of broiler chicks. Anim Feed Sci Technol 66, 149-158.

30. Rymer C \& Givens DI (2010) Effect of vitamin E and fish oil inclusion in broiler diets on the fatty acid composition and detection of flavour differences in chicken breast meat. J Sci Food Agric 90, 1628-1633.

31. Arakawa K \& Sagai M (1986) Species differences in lipid peroxide levels in lung tissue and investigation of their determining factors. Lipids 21, 769-775. 